\title{
Relationship Adolescent perceptions about the maturity of the reproductive organs with sexual behavior deviations
}

\author{
Riana Safitri ${ }^{1}$, Mudjiran ${ }^{2}$, Z Mawardi Effendi $^{3}$ \\ ${ }^{123}$ Universitas Negeri Padang \\ ${ }^{*}$ Corresponding author, e-mail: rianasafitri92@gmail.com
}

\begin{abstract}
The deviations of sexual behavior are the behavior or behaviour that is not necessarily done by each individual in the course of teenagers as humans who are experiencing the transition or transitioning as not in accordance with the norms Applicable, whether it is religious norms, customs and legal norms. Nowadays, there have been many sexual behavior deviations done by the teenagers such as holding hands with the opposite sex, embracing, kissing, and even having intercourse like a husband and wife. Sexual behavior deviations are caused by internal and external factors. Internal factors can occur due to the sexual arousal that occurs in the age of adolescence and want to channel it to the opposite sex, while external factors can occur due to the environment that makes adolescents commit sexual behavior irregularities, as there are pornographic sites seen by teenagers, then they demonstrate with the opposite sex and lack the education. The purpose of this research is to look at the adolescent perception relationship about the maturity of reproductive tools with sexual behavior deviations. This study uses propotional stratiefied random sampling techniques. Based on research done, it was found that there was a significant link between juvenile perception of the maturity of reproductive tools and sexual behavior deviations.
\end{abstract}

Keywords: adolescent perception, maturity of reproductive organs, sexual behavior deviations

\section{Introduction}

Adolescence is part of life's journey and it is not a period of change in isolated developments. Although adolescents have a characteristic, occurring in adolescence are interconnected with the development and experience of childhood and adult. At this time teenagers are prone to influence from the outside whether it is a positive or negative influence. This is in accordance with Ericson's opinion stating that adolescence is a very critical time and adolescence can be the best of time and the worst of time (Yuliet, Savitri, \& Chotim, 2017). 
Teenagers also generally have a great curiosity about the new things they saw and felt. A large curiosity makes the individual interpret the information obtained, because in managing the stimulus or information involves a process of cognition, where the individual has an existing stimulus. This can cause the individual to pose a perception himself. Individuals with good levels of cognition tend to have a good perception of the object they sees. As it is discovered by (Listyana \& Hartono, 2015), that in perception contains a process in itself to know and evaluate the extent to which individuals know others. In this process the sensitivity in a person to the environment is beginning to be seen. Perspective will determine the resulting impression of the perception process.

Perception is the direct response of a person through a system that is complex in accepting and understanding a phenomenon that uses the sensory equipment so that the perception is generated by cooperation between factors from within (personal) that together assert Perception of a person (Arisana \& Ismami, 2012). Perception is the process of entering the stimulus by the human senses that are then organized and understood which ultimately results in a view, observation or response to a stimulus object that could be objects, events, human behaviour, and the effect it has brought (Yuniarti, 2009).

The emergence of perception in adolescence is one of the consequences of the process of functioning of adolescent body organs as well as changes in behavior and environment. The most important organ process of puberty is sexual maturity. At the age of teenagers just entering maturity will lead to heightened fantasy and sexual feelings. This makes the youth try to realize the fantasies that have been in his mind in the form of distorted sexual behavior. Sexual behavior deviations among ordinary adolescents begins with a romantic relationship that is rooted in the physical changes in puberty. This is the initiation of the youth to turn to and eventually become deviant behavior, namely sexual behavior that is caused by the biological change of puberty as well as changes in the level of interpretation in individuals (Moore \& Harden, 2014).

Sarwono (2010) suggests that sexual behavior is a behavioral-driven sexual desire with the opposite sex. These kinds of behaviors such as starting from each other between the opposite sex, the behavior of dating, kissing to the body. Deviant sexual behavior that is not appropriate and also deviates with religious norms or legal or moral norms, which is commonly done by teenage couples. This is what makes the behaviour avoided by all individuals (Aisyah, 2017).

Risdawati (2014), argues that behavioral deviations resulted from discrepancies between actors in realizing aspirations with the prevailing rules and regulations in place of residence. Sarwono (2010), suggests that premarital sexual behaviour is any form of behavior with sexual compulsions by using reproductive function or which stimulates the sensation of receptors located in or around organs reproduction and erogenous areas to obtain sexual pleasure or pleasure performed by a man and a woman prior to a bond or covenant as an official husband of the wife and the absence of wishes or commitment to forming a family.

Growing and technological advances nowadays will make it easier for teenagers to access things with negative content, one of them access on social media. Greenbeerg explains adolescents getting classified information about $21 \%$ sex obtained from home, $15 \%$ from school, $28 \%$ from mass media and film as well as $40 \%$ of peers (Firman, Nirwana, \& Syahniar, 2017). This can make it easier for teenagers to put on deviant behavior, such as 
courtship, holding hands, kissing and fonding, that is because something he often sees will be of curiosity to try it out with the opposite.

The relationship of adolescents who experience the maturity of reproductive equipment with sexual behavior deviations is the early puberty, the sooner the youth experience identity crisis, all the concerns that occur due to physical change and increasingly making Teenagers want to find out and want to try what he hasn't known including sexual problems. Also, the active onset of sexual hormones leads to a sexual boost in adolescents. Therefore, teenagers often feel that it is time to do sexual activities because they feel they are physically ripe (Mahmudah, Yaunin, \& Lestari, 2016).

Haryani, Mudjiran, \& Syukur (2012), suggests that adolescents tend to do sexual activities, in medical sciences and other related sciences, adolescents are also referred to as a physical development stage where the genitals in adolescents Reach its fame. Anatomically means the genitals and the state of the body generally get the perfect shape and it has functioned perfectly. If at the moment it reaches the level of its youth, it does not get a good degree of sex, it will cause distorted sexual behavior. The purpose of this research is to look at the adolescent perception relationship about the maturity of reproductive tools with sexual behavior deviations.

\section{Method}

This research is quantitative research using a correlational approach aimed at knowing the relationship between the research variables of adolescents ' perception of the maturity of reproductive tools (variable $\mathrm{x}$ ) and behavior deviations Sexual (variable y). The samples in this study were 250 learners in MTs Negeri 1 Payakumbuh. Before determining the number of research samples, there was a population determination. The step done in population determination is to classify all MTs students Negeri 1 Payakumbuh which amounted to 665 people. Then the number of samples determined to apply Slovin formula, namely::

$S=$ $\frac{\mathrm{n}}{\text { n. } \mathrm{e}^{2}+1}$ (Yusuf, 2014)

Note: $\quad S=$ sample

$\mathrm{N}=$ population

$\mathrm{e}^{2}=$ degree of accuracy or critical value desired (0.5)

This research instrument is comprised of adolescent perception instruments on the maturity of a reproduction device amounting to 22 items and an instrument of 28 sexual behavior deviations totalling the 28th item, the overall item amounted to 50 items. The questionnaire used the Likert scale with an alternate answer of the adolescent perception instrument on the maturity of the reproductive device: it is suitable, suitable, reasonably appropriate, inappropriate, very inappropriate, and alternative to the instrument of irregularities Sexual behaviors are: always, often, sometimes, rarely, never. To test the validity of the research using the product moment analysis, it obtained the results of 50 items of the vaild of 61 items, and there are 11 items of declaration stated invalid. In order to find the level of belief or to determine the level of reliability of this research instrument, it is done 
by comparing Cronbach Alpha minimum value with Cronbach alpha instrument. The reliability test results obtained alpha value of the research instrument of 0.849 is greater than the prescribed criteria $(0,849>0,80)$, thereby it can be said that the research instrument is reliable. The processing of this research data is done using the help of SPSS (Statistical Product and Service Solution) for Windows release 20.00.

\section{Results and Discussion}

The results of research on adolescent perceptions about the maturity of the reproductive organs

Table 1. Description Mean (Percentage) and Percentage (\%) Youth Perception concerning Maturity of Reproductive Equipment (X) Based on Subvariables

\begin{tabular}{lccccccccc}
\hline \multirow{2}{*}{ No } & Sub & \multicolumn{10}{c}{ Score } \\
\cline { 3 - 10 } & Variabel & Ideal & Max & Min & $\Sigma$ & Mean & $\%$ & Sd & Ket \\
1 & Kognisi & 45 & 35 & 11 & 5577 & 22,31 & 49,57 & 5,44 & $\mathrm{R}$ \\
2 & Afeksi & 65 & 54 & 16 & 7936 & 31,74 & 48,83 & 6,80 & $\mathrm{R}$ \\
\multicolumn{2}{l}{ Keseluruhan } & 110 & 89 & 17 & 13.513 & 54,05 & 98,4 & 12,24 & $\mathrm{R}$ \\
\hline
\end{tabular}

Information:

Max: Highest Scores obtained by Students

Sd: Standard Deviation

Min: The lowest score obtained by students

R: Low

From the results of the instruments that have been propagated to the learners, it is found that on average the level of adolescent perception of the maturity of student reproductive tools is in the low category. A low category is meant that students ' responses or assumptions about changes that exist in students, whether they are low in physical or psychic changes. The table above shows that the average percentage of the achievement score for a sub variable of its recognition achievement is almost all the highest compared to sub-variable cognition which means the child's view or assessment of the maturity of the reproduction tool is more lower than the child's feelings about reproductive maturity. The table above also shows that the lowest percentage of the access score is in the affection subvariable which is $46.49 \%$. The conclusion that can be taken is the overall percentage of the achievement score is in the low category, but for each sub variable has a different level of achievement even though it remains in one category.. 
The results of research on sexual behavior deviations

Table 2. Description Average (Mean) and Percentage (\%) Behavioral Deviations Sexual (Y) Based on Subvariables

\begin{tabular}{cccccccccc}
\hline \multirow{2}{*}{ No } & Sub & \multicolumn{10}{c}{ Skor } \\
\cline { 3 - 9 } & Variabel & Ideal & Max & Min & $\Sigma$ & Mean & $\%$ & Sd & Ket \\
2 & Norma & 90 & 90 & 58 & 20515 & 82,06 & 91,18 & 7,141 & ST \\
2 & Adat/ & 50 & 50 & 31 & 11751 & 47,00 & 94 & 3,07 & ST \\
& kebiasaan & & & & & & & & \\
& Keseluruhan & 140 & 140 & 89 & 32.266 & 129,06 & 185,18 & 10,2 & ST \\
\hline
\end{tabular}

Information:

Max: Highest Scores obtained by Students

Sd: Standard Deviation

Min: The lowest score obtained by students

ST: Very high

From the results of the instruments that have been propagated to the learners, the results are found that on average the level of sexual behavior deviations in learners is in very high categories. The table above shows that scores for sub-variables of religious norms and customs/habits are in very high categories. Based on these sub-variables, the category is very high in that the average student is aware of the prevailing norms in religion and customs, but learners as a teenager still conduct sexual behavior deviations in their daily lives.

\section{Discussion}

Based on the results of the research that has been outlined, it is proven that the perception of adolescents on the maturity of reproductive equipment in MTS Negeri 1 Payakumbuh in class VII and IX is low. The factors that can lead to the perception of students are because of the curiosity of the object that is seen or felt. The results of the above studies are in line with the theory expressed by Listyana \& Hartono (2015), which suggests that in perception contains a process in itself to identify and to know an object. Then Daryl Benn suggests that self-perception simply means someone to make a conclusion yourself according to how to think and experience by observing the behavior of another person or object (Yazid \& Ridwan, 2017).

The object referred to in this study is the process of maturity of reproductive organs that is being experienced and perceived by students, because students are experiencing puberty or growing from childhood to adolescence. The process is called the maturity of reproductive equipment in adolescents.

Based on the results of the analysis and categories of data on variable sexual behavior deviations showed that the level of sexual behaviour deviation in class VII and IX in MTS Negeri 1 Payakumbuh is very high. There are several factors that may result in the onset of sexual behavior deviations in adolescents, internal and external factors. One internal factor causes the onset of sexual behavior deviations because of the desire of the individual to channel his desires. One of the causes of external factors is the environment and 
development of the increasingly sophisticated era, as well as the lack of religious education and sex received that could affect adolescents to conduct sexual behavior deviations.

The results of the study are in line with the theory that Darmasih, Setyadi, \& Gama (2011), said that the factors influencing the sexual behavior irregularities are peer-to-peer negative pressure relationships, religious-level understanding (religiosity), and exposure to pornography media has a significant influence, whether direct or indirect against the irregularities of adolescent sexual behavior.

Then Purnamaningsih (2015), in the results of his research suggests that the factors that affect the occurrence of sexual behavior deviations in adolescents, among others, media technology, environment, personality and culture. All of these factors work synergistically with one another thereby affecting sexual behavior irregularities.

\section{Conclusion}

Based on the results and research discussion, it can be concluded that on average, the depiction of adolescents perception of the hand of reproductive organs is in a low category, which means that students ' assumptions or responses are less than good, students are not fully aware of and understand the reproductive maturity that happens to him.

On average the rate of deviations of students ' sexual behavior is in a very high category, meaning that students feel they are young and can channel their desires that they think are appropriate, even if the students do not know the effects of the deeds they do or whether they are poor behavior. This is because some students consider if behavior such as holding hands, embracing or hugging the moment of sex and kissing is the usual thing that other teenage couples do. They lack the impact that such behavior is included in the declaration of sexual behavior. Therefore, the sexual behavior deviations in students are very high in MTS Negeri 1 Payakumbuh. From the research carried out the results that there is a significant relationship between the perceptions of adolescents about the maturity of reproductive organs with sexual behavior deviations is negative correlation.

\section{References}

Aisyah, S. (2017). Studi kasus penyimpangan perilaku seksual pada remaja tunalaras tipe conduct disorder. Jurnal Widia, 6(8).

Arisana, L. A., \& Ismami. (2012). Pengaruh kedisiplinan siswa dan persepsi siswa tentang kualitas mengajar guru terhadap prestasi belajar akuntansi siswa kelas XI IPS MAN Yogyakarta II tahun ajaran 2011/2012. Jurnal Pendidikan Akuntansi Indonesia, 10(2), 22-42.

Darmasih, R., Setyadi, N. A., \& Gama, A. (2011). Kajian perilaku seks pranikah remaja SMA di Surakarta. Jurnal Kesehatan, 4.

Firman, Nirwana, H., \& Syahniar. (2017). The effektiveness of information service in improving student self control against sexual harrasement in vocational school in padang. Universitas Negeri Padang.

Haryani, M., Mudjiran, \& Syukur, Y. (2012). Dampak pornografi terhadap perilaku siswa dan upaya guru pembimbing untuk mengatasinya. Jurnal Ilmiah Konseling, 1(1).

Listyana, R., \& Hartono, Y. (2015). Persepsi dan sikap masyarakat terhadap penanggalan jawa dalam penentuan waktu pernikahan (studi kasus desa jonggrang kecamatan barat kabupaten magetan). 
Jurnal Agastya, 3(1).

Mahmudah, Yaunin, Y., \& Lestari, Y. (2016). Faktor-faktor yang berhubungan dengan perilaku seksual remaja di kota Padang. Jurnal Kesehatan Andalas, 5(2).

Moore, R. S., \& Harden, P. K. (2014). Pubertal timing and adolescent sexual behavior in girls. American Psychological Association, 50.

Purnamaningsih. (2015). Modalitas agama dalam gejala posspiritualitas penyimpangan seksualitas pelajar di kota denpasar. Jurnal Penelitian Agama, 1 .

Risdawati. (2014). Upaya bimbingan dan konseling islam dalam mengatasi perilaku menyimpang. Jurnal Hikmah, 8.

Sarwono, S. W. (2010). Psikologi Remaja. Jakarta: Rajawali Pers.

Yazid, T. P., \& Ridwan. (2017). Proses persepsi diri mahasiwa dalam berbusana muslimah. Jurnal Pemikiran Islam, 4(2), 193.

Yuliet, S., Savitri, N., \& Chotim, M. (2017). Perception of peer sexual behavior: do adolescent believe in a sexual double standard. American School Health Association, 1(1).

Yuniarti, N. Y. (2009). Hubungan persepsi efektivitas komunikasi interpersonal orangtua dan kematangan emosi dengan penyesuaian diri pada remaja siswa SMAN I Polanharjo. Universitas Sebelas Maret. 